\title{
Some Properties of Cocoa Swollen-Shoot Virus
}

\author{
By A. A. BRUNT* AND R. H. KENTEN \\ West African Cocoa Research Institute, Tafo, Ghana $\dagger$ \\ AND H. L. NIXON \\ Rothamsted Experimental Station, Harpenden, Hertfordshire
}

(Received 16 March 1964)

\begin{abstract}
SUMMARY
Partially purified preparations of the Kofi Pare isolate of cocoa swollenshoot virus (CSSV) were usually inactivated after $10 \mathrm{~min}$. at $50^{\circ}$, but not after $10 \mathrm{~min}$. at $45^{\circ}$. Infectivity of freshly made preparations was greatly lessened by diluting $1 / 10$, and lost at $1 / 100$. The infectivity of preparations increased after storage for $24 \mathrm{hr}$; after $96 \mathrm{hr}$ infectivity was retained at $0-4^{\circ}$ but soon lost at $25^{\circ}$. The virus survived freezing in vitro and, with some loss of infectivity, freezing in leaves and storage in leaves dried over aluminium oxide. Infective material was precipitated from dilute extracts by half saturation with ammonium sulphate at $\mathbf{2 5}^{\circ}$; it appeared to be equally stable over the range $\mathrm{pH} 6$ to $\mathrm{pH} 8$. Preparations of the symptomatologically distinct Kofi Pare, Mampong, Dawa, Nsaba and Bosomuoso isolates all contained similar rod-shaped particles of size about $121 \times 28 \mathrm{~m} \mu$.
\end{abstract}

\section{INTRODUCTION}

The availability of infective preparations of cocoa swollen-shoot virus (Brunt \& Kenten, 1963) has made it possible to examine the properties of the virus in vitro. We report here some of the properties of partially purified preparations of the Kofi Pare isolate, and the electron microscopy of this and four other symptomatologically distinct isolates.

\section{METHODS}

The cocoa swollen-shoot virus (CSSV) isolates from Kofi Pare, Bosomuoso, Mampong and Nsaba in Ghana were derived from cultures described previously (Brunt \& Kenten, 1963); an isolate from Dawa (Eastern Region, Ghana) was also used. The Kofi Pare isolate, which is indistinguishable from Posnette's (1947) swollen-shoot virus strain A or virulent New Juaben strain, was used throughout, and the others for electron microscopy only.

The viruses were extracted from the leaves of infected cocoa seedlings and partially purified by methods similar to those described previously (Brunt \& Kenten, 1963). Twenty-five g. infected first-flush cocoa leaves were ground in a Waring Blendor for $1 \mathrm{~min}$. in $500 \mathrm{ml}$. of a solution at $\mathrm{pH} \mathrm{8.0-8.2} \mathrm{containing} 0.05 \mathrm{M}-$ disodium hydrogen phosphate, $0.05 \mathrm{M}$-thioglycollic (mercaptoacetic) acid, $0.005 \mathrm{M}$ sodium diethyldithiocarbamate and 1 or $2 \%(w / v)$ hide powder (Hopkin \& Williams

* Present address: Glasshouse Crops Research Institute, Rustington, Sussex.

$\dagger$ Since renamed Cocoa Research Institute, Ghana Academy of Sciences. 
Ltd.). This hide powder was first thoroughly dispersed in the solution by running the Waring Blendor at full speed for $3 \mathrm{~min}$. before adding the leaves. The suspension was squeezed by hand through cotton cloth and clarified by centrifugation at $8000 \mathrm{~g}$ for 5-10 min. The virus was then sedimented by centrifuging the supernatant fluid at $75,000 \mathrm{~g}$ for $2 \mathrm{hr}$. The pellets were usually dispersed in a solution at $\mathrm{pH} 8.0$ containing $0.01 \mathrm{M}$-disodium hydrogen phosphate and $0.01 \mathrm{M}$-thioglycollic acid, using about $1 / 35$ of the volume of the original extract.

Because the original difficulties in transmitting CSSV by sap inoculation (Brunt $\&$ Kenten, 1960, 1962b) might have been caused by instability of the virus, at first all extracts were made as quickly as possible, with chilled apparatus and solutions. However, later extractions were made at room temperature (about $25^{\circ}$ ), after it was found that such extracts were usually more infective than those made below $8^{\circ}$.

All infectivity tests were made by inoculating whole cocoa beans; to increase the number of infections a little 'Celite' 545 (Johns Manville Ltd.) was added to all inocula.

Electron microscopy was done at Rothamsted Experimental Station, with samples of virus preparations made and tested for infectivity in Ghana and sent to the United Kingdom by air in chilled vacuum flasks. On arrival they were clarified by centrifugation at $8000 \mathrm{~g}$ for $10 \mathrm{~min}$. and the virus again sedimented from the supernatant fluid by centrifuging at 75,000 $\mathrm{g}$ for $2 \mathrm{hr}$. The greenish pellets were dispersed in 1-2 ml. of 0.1 M-ammonium acetate and used for electron microscopy after brief centrifugation at $8000 \mathrm{~g}$ to remove insoluble material. Preliminary experiments showed that satisfactory shadowcast mounts could not be made from these preparations because they still contained mucilage even after two cycles of differential centrifugation. All electron microscopy was therefore done with mounts made by a negative staining technique (Brenner \& Horne, 1959). Most microscopy was done at $\times 20,000$ magnification; some pictures were taken at $\times 80,000$. Particle lengths were measured either from the original photographic plates by using a scale graduated in $\mathbf{0 . 5} \mathrm{mm}$. steps and a hand lens, or were estimated by measuring the image projected by a calibrated photographic enlarger.

\section{RESULTS}

\section{Properties of the virus in vitro}

The properties of the virus were determined by using preparations made from clarified cocoa leaf extracts by one cycle of high-speed centrifugation. The sedimented virus was dispersed in phosphate+thioglycollate solution of $1 / 35$ th the original volume; any further dilutions were also made in the same phosphate+ thioglycollate solution. Since the leaves had originally been macerated in 20 volumes of the extracting solution, each $1 \mathrm{ml}$. of these partially purified preparations was derived from $1 \cdot 75 \mathrm{~g}$. fresh leaf.

Dilution end-point. When tested fresh, the infectivity of preparations was greatly diminished by diluting 1/10 and abolished by diluting 1/100. After storage for $\mathbf{2 4} \mathrm{hr}$, however, infectivity increased (see below) and infections were obtained at 1/100 (Table 1).

Stability in vitro. Preparations of virus were kept in loosely stoppered test tubes at $0-4^{\circ}$ or $25^{\circ}$ and tested for infectivity after 24,48 and $96 \mathrm{hr}$. After $24 \mathrm{hr}$ the 
infectivity of both samples increased; on storage up to $96 \mathrm{hr}$ there was little further change in the infectivity of samples stored at $0-4^{\circ}$ but those kept at about $25^{\circ}$ lost much of their infectivity.

Thermal inactivation. One-ml. samples of virus preparation were heated for $10 \mathrm{~min}$. to various temperatures. Infectivity, seemingly unaffected by heating up to $45^{\circ}$, was lost at $50^{\circ}$ or above, except for a single infection which was obtained from one sample heated to $55^{\circ}$ (Table 2).

Table 1. Stability of cocoa swollen-shoot virus in vitro at room temperature (about $25^{\circ}$ ) and $0-4^{\circ}$

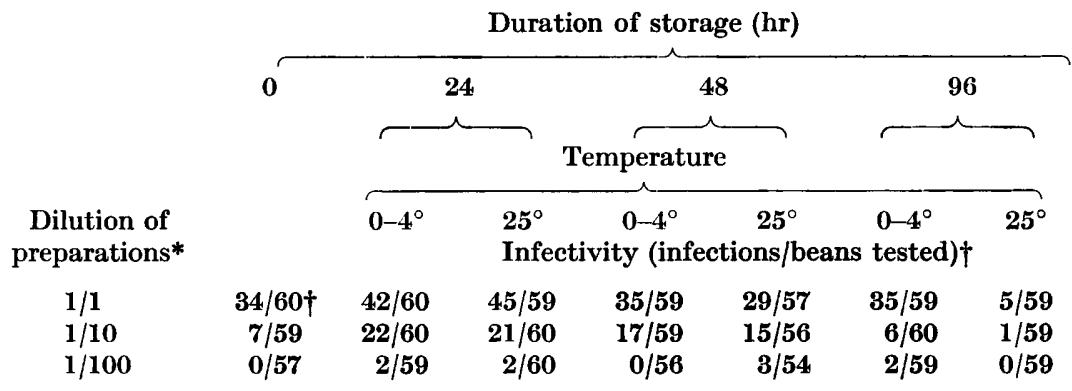

* Dilutions were made after storage with a solution ( $\mathrm{pH} \mathrm{8)}$ containing 0.01 M-disodium hydrogen phosphate and 0.01 M-thioglycollic acid.

$\dagger$ The denominator is the total number of whole cocoa beans inoculated in two experiments and the numerator the number of plants which were infected. Beans failing to germinate were omitted from the denominator.

Table 2. Thermal inactivation of partially purified preparations of cocoa swollen-shoot virus

\begin{tabular}{|c|c|c|c|c|c|}
\hline \multirow{3}{*}{$\begin{array}{c}\text { Dilution of } \\
\text { preparations* }\end{array}$} & \multirow[b]{3}{*}{ Unheated } & \multicolumn{4}{|c|}{ Preparations heated for $10 \mathrm{~min}$. } \\
\hline & & $45^{\circ}$ & $50^{\circ}$ & $\mathbf{5 5}^{\circ}$ & $60^{\circ}$ \\
\hline & & \multicolumn{4}{|c|}{ Infectivity (infections/beans tested) } \\
\hline $1 / 1$ & $19 / 60$ & $\mathbf{2 3} / 59$ & $0 / 60$ & $1 / 58$ & $0 / 60$ \\
\hline $1 / 10$ & $6 / 60$ & $5 / 60$ & $0 / 60$ & $0 / 60$ & $0 / 60$ \\
\hline
\end{tabular}

* Dilutions made with a solution (pH 8) containing $0 \cdot 01 \mathrm{M}$-thioglycollic acid and $0 \cdot 01 \mathrm{M}$-disodium hydrogen phosphate after heating $1 \mathrm{ml}$. virus samples.

Effect of freezing and desiccation. Preparations of virus from leaves which had been frozen for $24 \mathrm{hr}$ or dried in vacuo over aluminium oxide before they were extracted were infective, but slightly less so than those made from fresh leaves (Table 3). Freezing had little effect upon the infectivity of clarified sap or the partially purified preparations.

Precipitation with ammonium sulphate. In preliminary tests (Brunt \& Kenten, $1962 a$ ) the sparse precipitate formed when ammonium sulphate was added to clarified cocoa leaf extracts, prepared by grinding leaves in extracting fluids containing no added protein, was not infective. However, when extracts made with fluid containing added protein $(2 \%, \mathrm{w} / \mathrm{v}$, hide powder) were half-saturated with ammonium sulphate at $25^{\circ}$ the bulky precipitate produced was infective. After 
dialysing the resuspended precipitate against phosphate +thioglycollate solution

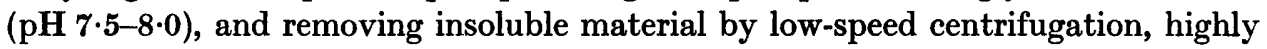
infective preparations were obtained by sedimenting the virus from the supernatant fluid.

Effect of $p H$ value. Preparations were dispersed in phosphate + thioglycollate solution adjusted to $\mathrm{pH} 6,7$ and 8 , and samples tested for infectivity immediately and after 24 and $48 \mathrm{hr}$. All were similarly infective (Table 4).

Table 3. Effects of drying or of freezing infected leaves on virus

In each experiment thirty whole cocoa beans were inoculated with each of six samples. Infected leaves were frozen for $24 \mathrm{hr}$. Shredded leaves were dried in vacuo for $24 \mathrm{hr}$ over aluminium oxide.

Leaves processed

$\begin{array}{cccc} & \overbrace{\begin{array}{c}\text { Immediately } \\ \text { Infectivity (infections/beans tested) }\end{array}}^{\begin{array}{c}\text { After freezing } \\ \text { After desiccation }\end{array}} \\ \text { Expt. no. } & & 20 / 174 & 32 / 172 \\ 1 & 32 / 164 & 48 / 179 & 16 / 136 \\ 2 & 66 / 180 & 57 / 180 & - \\ 3 & 63 / 171 & 125 / 533 & 48 / 308 \\ \text { Total } & 161 / 515 & \mathbf{2 3 . 5} & 15 \cdot 6 \\ \text { Mean (\%) } & 33 \cdot 3 & & \end{array}$

Table 4. Effect of $p H$ value on stability of partially purified virus

$\begin{array}{cccc}\begin{array}{c}\text { Suspending } \\ \text { solution } \\ \text { at pH }\end{array} & \overbrace{\overbrace{\text { Infectivity (infections/beans tested) }}^{24}}^{\text {Duration of treatment (hr) }} \\ 6 & & 16 / 40 & 11 / 30 \\ 7 & 17 / 40 & 24 / 40 & 13 / 30 \\ 8 & 22 / 38 & 23 / 40 & 15 / 30\end{array}$

Electron microscopy

Presence of particles. All virus preparations made from plants infected with the CSSV isolates tested contained rod-shaped particles; such particles were never found in preparations made in the same way from healthy plants. No formal correlation between particle numbers and infectivity was attempted, but more such particles were found in highly infective preparations than in less infective ones.

Morphology of the particles. The particles were straight or slightly curved, with rounded ends (Plate 1). Preparations of the isolates from Kofi Pare, Mampong and Nsaba contained enough particles to permit making histograms showing the length distribution (Fig. 1); particles of the Dawa and Bosomuoso isolates, although too few to construct histograms, gave indications of a similar length-distribution pattern. Because the distribution is skew, no valid estimate of the most common length can be made by taking the mean of all particles measured. We have overcome this difficulty by selecting a narrow range of sizes symmetrically placed about the most common length shown in the histogram, and using only particles falling within the range to estimate the most common length (Brandes \& Paul, 1957). 
Table 5 shows the mean value obtained for the three isolates by this method. The lengths of particles in preparations made from cocoa plants infected with the Kofi Pare, Mampong and Nsaba CSSV isolates are all similar.

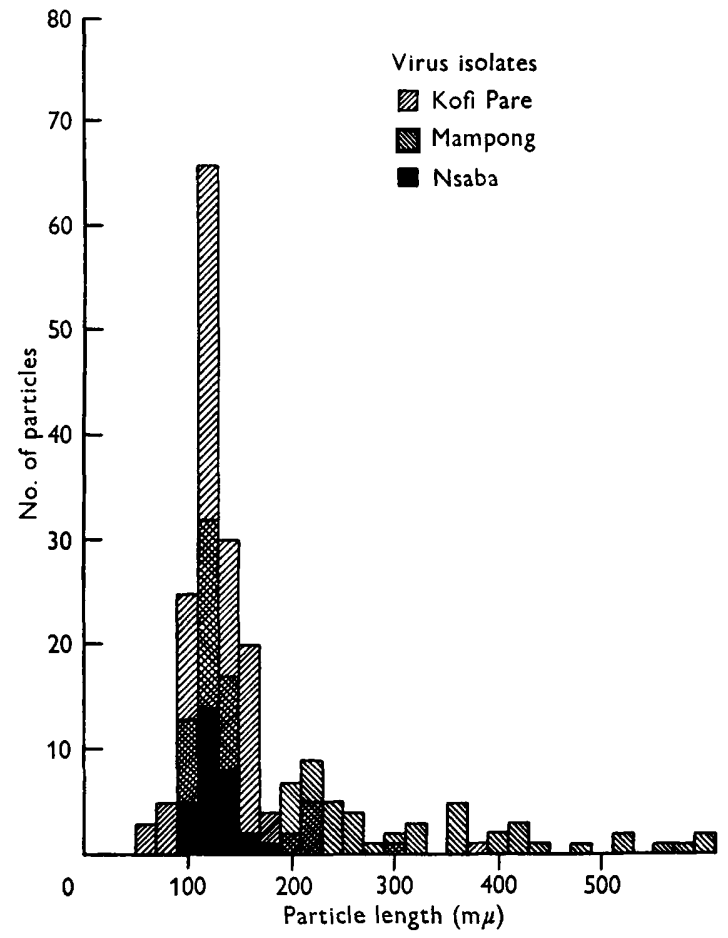

Fig. 1

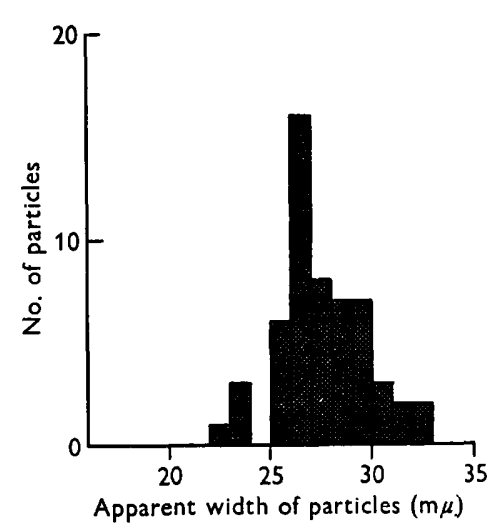

Fig. 2

Fig. 1. Length distribution of particles found in virus preparations from plants infected with three isolates of cocoa swollen-shoot virus.

Fig. 2. Widths of particles seen in electron micrographs of cocoa swollen-shoot virus preparations.

Table 5. Dimensions of virus-like particles extracted from cocoa leaves infected with three isolates of cocoa swollen-shoot virus

\begin{tabular}{|c|c|c|c|c|}
\hline Virus isolate & $\begin{array}{c}\text { Number of } \\
\text { particles } \\
\text { measured }\end{array}$ & $\begin{array}{c}\text { Particles } \\
\text { in 91-150 m } \mu \\
\text { group } \\
(\%)\end{array}$ & $\begin{array}{c}\text { Mean length } \\
\text { of } 91-150 \mathrm{~m} \mu \\
\text { particles }\end{array}$ & Width $(\mathrm{m} \mu)^{*}$ \\
\hline pare & 102 & $60 \cdot 8$ & $119 \cdot 6$ & $26.7 \pm 0.4$ \\
\hline mpong & 162 & $82 \cdot 1$ & $122 \cdot 2$ & $29 \cdot 1 \pm 1 \cdot 8$ \\
\hline ba & $\mathbf{3 0}$ & $90 \cdot 0$ & $122 \cdot 7$ & $28.9 \pm 4.0$ \\
\hline isolates together & 294 & $75 \cdot 9$ & $121 \cdot 0$ & $27 \cdot 9$ \\
\hline
\end{tabular}

* Particle widths estimated from micro-densitometer traces across the images.

Estimates of particle width were taken from micro-densitometer traces made across the images on the original plates. The values obtained (Fig. 2) almost certainly underestimate the true particle width, because of penetration of the phospho- 
tungstate (PTA) into the outer parts of the particles; this occurs even with extremely stable viruses such as tobacco mosaic, particles of which appear to be only $12 \mathrm{~m} \mu$ wide instead of $15 \mathrm{~m} \mu$ when measured from shadowed mounts. The particles appear to be tubular, with their centres filled with PTA (Plate). The rounded ends are an unusual feature and we know of only one other rod-shaped virus particle (lucerne mosaic) with rounded ends (Gibbs, Nixon \& Woods, 1963). Whether the rounded ends of the CSSV particles represent an essential part of their structure, or merely show that the ends of the particles are degraded, is uncertain; we incline to the latter view because a few particles in some of our better extracts have had one or both ends cut off square. No other structures could be seen in the particles, even in micrographs of good quality made at $\times 80,000$.

Although it is not known that the particles observed in the electron microscope are those of CSSV, their size, shape, general appearance, and the fact that their presence appears to be correlated with infectivity, all suggest that they are the virus.

\section{DISCUSSION}

Cocoa swollen-shoot virus (CSSV), cocoa mottle leaf virus and strains A and в of the virus which occurs in Trinidad (Baker \& Dale, 1947) are the only viruses known with certainty to be transmitted by mealybugs. It is therefore of particular interest that at least one isolate of CSSV can be studied and characterized in vitro. Because we have determined some of the properties of CSSV in partially purified preparations, no direct comparison with those of most other viruses is possible. However, our results clearly show that CSSV is moderately stable once it has been separated or protected from some constituents of cocoa leaves. Initial difficulties in transmitting the virus by mechanical inoculation (Brunt \& Kenten, 1960, 1962b) therefore probably reflected the release of inhibitors of infection when cocoa leaves were macerated, rather than any intrinsic instability of the virus or an unusually small virus concentration in the leaf. Indeed preparations, which on a leaf weight basis were less than twofold concentrated, were not only infective but were so when diluted 1/10 and occasionally 1/100. No attempt was made to identify these inhibitors but, since 'vegetable tannins' occur abundantly in cocoa leaves (Holden, 1957) and inactivate other viruses (Cadman, 1959; Thresh, 1956), Brunt \& Kenten (1963) suggested that these are the leaf constituents which inactivate CSSV when cocoa leaves are macerated. The protective effect of protein was explained by postulating that the 'vegetable tannins' combine with this rather than with the virus. However, fixation of tanning substances by proteins is related to the charge carried by the protein, fixation by vegetable tannins increasing with net positive charge. By contrast, fixation of aldehydes by proteins increases with net negative charge, so that at or about $\mathrm{pH} 8$ it might be expected that proteins would fix aldehydes more readily than vegetable tannin. For this reason leaf aldehydes may also be important inhibitors of infection by CSSV in alkaline extracts of cocoa leaves.

Although our attempts to prepare antisera to the Kofi Pare CSSV isolate failed, now that the virus is known to be relatively stable in vitro, it will be worth trying to prepare antisera by using more concentrated preparations as antigens. In making such preparations the need to ultracentrifuge large volumes of clarified extracts could 
be avoided by making a preliminary concentration by precipitating the virus from dilute extracts with ammonium sulphate.

The technical assistance of Messrs B. M. Lagudah and J. K. Bonney is gratefully acknowledged. We also thank Dr J. W. Blencowe for much help when attempting to prepare antisera. This paper is published with the permission of the Chairman of the Managing Committee of the West African Cocoa Research Institute.

\section{REFERENCES}

Baker, R. E. D. \& Dale, W. 'T. (1947). Notes on a virus disease of cacao. Ann. appl. Biol. 34, 60.

Brandes, J. \& Paul, H. L. (1957). Das Elektronenmikroskop als Hilfsmittel bei der Diagnose pflanzliche Virosen. Arch. Mikrobiol. 26, 358.

Brenner, S. \& Horne, R. W. (1959). A negative staining method for high resolution electron microscopy of viruses. Biochim. biophys. Acta, 34, 103.

Brunt, A. A. \& Kenten, R. H. (1960). Mechanical transmission of cocoa swollen-shoot virus. Virology, 12, 328.

Brunt, A. A. \& Kenten, R. H. (1962a). Virus research. Mechanical transmission of cocoa viruses. Rep. W. Afr. Cocoa Res. Inst. 1960-61, p. 22.

Brunt, A. A. \& Kenten, R. H. (1962b). Mechanical transmission of cocoa swollen-shoot virus to and from cocoa and other hosts. Ann. appl. Biol. 50, 749.

Brunt, A. A. \& Kenten, R. H. (1963). The use of protein in the extraction of cocoa swollen-shoot virus from cocoa leaves. Virology, 19, 388.

Cadman, C. H. (1959). Some properties of an inhibitor of virus infection from leaves of raspberry. J. gen. Microbiol. $20,113$.

Gibis, A. J., Nixon, H. L. \& Woons, R. D. (1963). Properties of purified preparations of lucerne mosaic virus. Virology, 19, 441.

Holden, M. (1957). An investigation on polyphenolic compounds of the cocoa leaf in connexion with a chemical method for detecting virus infection. J. Sci. Fd Agric. 8, 553.

Posnetre, A. F. (1947). Virus diseases of cacao in West Africa. I. Cacao viruses 1A, 1B, 1C and 1D. Ann. appl. Biol. 34, 388.

Thresh, J. M. (1956). Some effects of tannic acid and of leaf extracts which contain tannins on the infectivity of tobacco mosaic and tobacco necrosis viruses. Ann. appl. Biol. 44, 608.

\section{EXPLANATION OF PLATE}

Electron micrograph of particles found in preparations from plants infected with the Kofi Pare isolate of cocoa swollen-shoot virus. Negatively stained with phosphotungstate. 


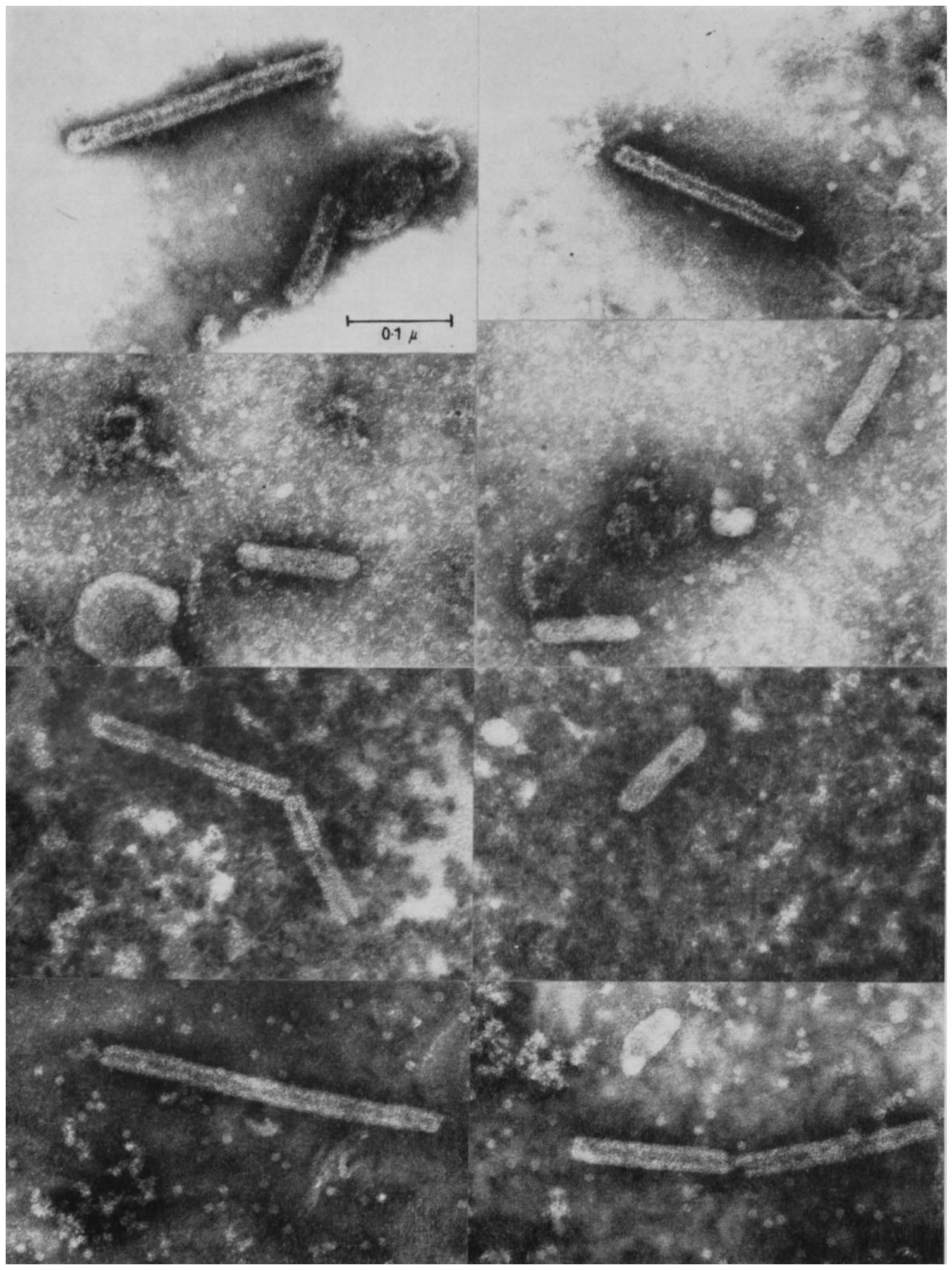

